\section{HSE}

Historia Social y de la Educación

Social and Education History
Hipatia Press

www.hipatiapress.com

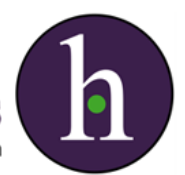

Instructions for authors, subscriptions and further details:

$\underline{\text { http://hse.hipatiapress.com }}$

\title{
The Development of Catholic Schools in the Republic of Sudan
}

Jorge Carlos Naranjo ${ }^{1}$

1) Sudan University of Science and Technology, Sudan

Date of publication: February $23^{\text {th }}, 2019$

Edition period: February 2019-June 2019

To cite this article: Naranjo, J. C. (2019). The development of catholic schools in the Republic of Sudan. Social and Education History, 8(1), 83111. doi:10.17583/hse.2019.3611

To link this article: http://dx.doi.org/10.17583/hse.2019.3611

\section{PLEASE SCROLL DOWN FOR ARTICLE}

The terms and conditions of use are related to the Open Journal System and to Creative Commons Attribution License (CC-BY). 


\section{The Development of Catholic Schools in the Republic of Sudan}

Jorge Carlos Naranjo Alcaide

Sudan Univeristy of Science and Technology

(Sudan)

\section{Abstract}

Sudan is today a country self-defined as Islamic (97\% of the population) and Arab. In this context the schools of the Catholic Church have played and play a relevant role in the instruction of the elites of the country and in the provision of education to the displaced and refugee communities (3.58 million persons of concern of UNHCR in 2016). This article studies the development of these schools and their change of role along the following historical periods: the part of the Turco-Egyptian rule that corresponds with the foundation of the first Catholic Schools and the work of the great promotor of education in Sudan, Daniel Comboni (1843-1881); the AngloEgyptian Condominium which meant their expansion (1898-1956); and the Independent Sudan where they mainly focused on the service to displaced and refugees (1956-2017). The article describes this evolution and the current situation based upon the revision of published bibliography and unpublished materials from the archives of the Education Office of the Archdiocese of Khartoum and of the Comboni Missionaries in Sudan, especially for the most recent periods.

Key words: Education, Sudan, Comboni, missionary schools 


\section{EI Desarrollo de las Escuelas Católicas en la República de Sudán}

Jorge Carlos Naranjo Alcaide

Sudan University of Science and Technology (Sudan)

\section{Resumen}

Sudán es hoy un país autodefinido como islámico ( $97 \%$ de su población) y árabe. En este contexto las escuelas de la Iglesia Católica han desempeñado y desempeñan un papel relevante en la instrucción de las élites del país y en la provisión de educación a las comunidades de desplazados y refugiados (3,58 millones de personas de interés del ACNUR en 2016). Este artículo estudia el desarrollo de estas escuelas y su cambio de rol a lo largo de los diferentes períodos históricos: la parte del gobierno Turco-Egipcio que corresponde con la fundación de las primeras Escuelas Católicas y el trabajo del gran promotor de la educación en Sudán, Daniel Comboni (18431881); el condominio anglo-egipcio que significó su expansión (1898-1956); y el período del Sudán Independiente, donde estas escuelas se concentraron principalmente en el servicio a los desplazados y refugiados (1956-2017). El artículo describe esta evolución y la situación actual a partir de la revisión de la bibliografía publicada y de materiales inéditos de los archivos de la Oficina de Educación de la Arquidiócesis de Jartum y de los Misioneros Combonianos en Sudán.

Palabras Clave: Educación, Comboni, escuelas de la misión 
atholic Schools in Sudan have played and still play a very
important role in the education of both the elites and the displaced
and refugee people. In order to understand the particular
characteristics of these schools and their current role in this concrete Islamic majority society there is need of travelling backwards through time.

\section{The First Catholic School in Khartoum}

The schools of the Catholic Church in Sudan are popularly known as "Comboni Schools". They take their name from an Italian missionary called Daniel Comboni (1831-1881) who in the Sudanese collective imagination is the founder of all these schools. In Sudanese academic literature they are usually known as "mission schools" (Sa'ād, 2002; 'Uthmān, 1949).

However, the first school of the Catholic Church in Khartoum was not opened by Comboni but by an Italian priest called Luigi Montuori in 1843 (Toniolo \& Hill, 1974, pp.1.35; Sa'ād, 2002, p. 44) with "some white, black and mulatto boys" (letter of Fr. Montuori written on March 12, 1843 and reported by Bano, 1979, pp. 201-202; Ballin, 2001, p. 96).

The students of this school were the children of freed slaves and of some Europeans who had been born in Khartoum. They just studied "reading and writing and the Gospel" (Sa'âd, 2002, p. 45). The school was a big hut made of wood and mud (Lozano, 1996, p. 70) and its scope was to train the students "to be catechists in their countries" (Ballin, 2001, p. 97). Fr. Luigi Montuori left Sudan in 1844 for Ethiopia after having entrusted the mission of Khartoum to another priest of his religious Congregation, the Lazarists. This latter missionary, Fr. Serao, left Sudan "between May and the Autumn of 1845" (Ballin, 2001, p. 99).

In 1846 Pope Gregorio XVI erected Khartoum as site for the Vicariate of Central Africa because of its strategic position on the junction of the Blue and White Nile. Therefore, it was feasible to reach this city from Europe through the Nile. This fact was remarkable if we consider that there were no good maps of the interior of the continent at the time. Khartoum seemed to be a suitable starting point for further explorations and expansions towards Ethiopia or the Equatorial Lakes.

The second Pro-Apostolic Vicar of Khartoum, Maximilian Ryllo, bought the plot at Nile Street where the Council of Ministers is located today at 


\section{Naranjo-Escuelas católicas de la República de Sudán}

Khartoum (Moḥamed Ibrahīm, 1991, p. 55; quoted by Ballin, 2001, p. 106) and in 1848 reopened there the school of Montuori "for negro children whom they bought in the slave market" (Hill, 1959, p. 79). In a second moment, the students were also Coptic and Europeans. They studied "writing and reading, mathematics, music, handwork, Arabic, French and Italian languages" (Sa'ād, 2002, p. 45). In 1850, already under the administration of the Apostolic Vicar who succeeded Ryllo, Dr. Knoblecher, the school consisted of one room in the only stone building of the time in Khartoum (Petherick, 1869; quoted by Toniolo \& Hill, 1974, p.4). The German geographer Carl Ritter reported the vision of that school:

The Catholic Mission intended to establish in Khartoum a day and a boarding school for boys of different negro tribes. In addition to the usual subjects they would be taught agriculture and handicrafts. After their training they would return to their tribes and become the instructors of their own people. (Ritter, 1852; cited in English by Toniolo \& Hill, 1974, p. 4)

Those ideas would be later included by Comboni in his Plan for the Regeneration of Africa along with the principle that these schools were not just conceived as places where European missionaries taught African students. Also European missionaries were supposed to learn from African people "the language of the different tribes; [...and] facts that could make known their character, habits and customs" (Toniolo \& Hill, 1974, p. 5).

In 1853 the person in charge of the boys' school was a priest from Slovenia called Fr. Matthew Milharcic. The school had 40 boys (Toniolo \& Hill, 1974, p.8). On that same year, this missionary started the construction of the big mission building that is currently the site of the Council of Ministers. Girls were also admitted in the school in a second moment and other sections were added: commerce, carpentry, welding, tailoring and production of shoes.

From the fifties of the century until the Mahdi's revolution, the Ottoman authorities just opened five schools in different towns of northern Sudan (Zomrawi \& Eisa, 2017, p.1) and some new Koranic schools (khalwa, pl. khalāwi in Sudanese Arabic) that were added to the existing ones. In these schools, the pupils studied Arabic language, basic arithmetic, the Quran, and 
Islamic jurisprudence (Yahya, 1987; al-Mu'tasim, 2005 cited by SeriHersch, 2017, p.3).

On September 4, 1861, Propaganda Fide ${ }^{l}$ entrusted the Vicariate to the Franciscan Order but the quick death of 23 of their missionaries led the General Superior to decide their withdrawal from this mission. This fact led to the suspension of the erection of the Vicariate by the Holy See in 1867. In spite of this, a Franciscan priest, Fr. F. Pfeifer, and a lay Brother remained in Khartoum for nine years. After their departure, D. Stadel-Meyer and H. Schlatter took their place (Toniolo \& Hill, 1974, p. 18). Thus, when the Holy See decided to appoint Daniel Comboni as Pro-Vicar ${ }^{2}$ in 1872 in view of reopening the activities of the Vicariate, he had not to start from scratch.

\section{Daniel Comboni and the Foundation of the Educational Work of the Catholic Church in Sudan}

\section{The Origins of Comboni's Educational Vision}

Daniel Comboni was an Italian priest born in a small village of the North of the country called Limone sul Garda in 1831. His personal education had a great impact on his work in the Sudan later on. He came from a poor family but enjoyed the opportunity to have good education as he was admitted at Saint Carlo Institute of Verona, an institution run by "Don Mazza Institute". This Institute educated young boys who were "rich in intelligence and virtues but poor in financial means" (Vanzan, 1996, p. 110). One of their graduates, Angelo Vinco, became a Catholic priest and traveled to Sudan in 1847. When he came back in 1849, he instilled in the students of the Mazza Institute the desire to evangelize the continent (Ballin, 2001, pp. 104-106).

This Institute started welcoming African students from 1851 with the idea of training them to be promoters of both development and evangelization in their places of origin (Lozano, 1996, p. 82). In 1854 Daniel Comboni was ordained a priest and became spiritual director in the Mazza Institute. In this way, he had the opportunity of knowing the African students in depth. Through his service as spiritual guide, he could go beyond the stereotypes that European people of his time had in relation to African people.

In 1857 Don Mazza organized a missionary expedition to Sudan made of Daniel Comboni and other five members of the Institute. Three of them died 


\section{Naranjo-Escuelas católicas de la República de Sudán}

in Sudan. Daniel Comboni survived and was asked to come back to Italy. The Vicariate of Central Africa became the tomb of 57 priests and numerous lay missionaries that succumbed to the African climate from 1848 to 1862 (Gonzalez, 1993, p. 209).

After meeting several explorers and missionaries, Comboni analyzed the mistakes committed by the previous missionary attempts and elaborated a Plan for the Regeneration of Africa in 1864. In his analysis of previous attempts of evangelization, he underlined the "ineffectiveness and inadvisability" (Comboni, 2006, p. 858) of the initiative to take African people to Europe in order to train them. He instead proposed the identification of a "centre of operations in a place where Africans can live without changing and Europeans can live without succumbing" (Comboni, 2006, p. 859). Daniel Comboni proposed to create in those centres "Institutes for both sexes" (2006, p. 861) where young African men and women would be educated both in the "Catholic religion and in Christian civilization" (2006, p. 861).

It's important to understand that Comboni was a man of his time. Thus, even if he considered that African people should not be changed; in his mind, Catholic religion was condition for the eternal salvation of the person. These religious motivations went along with the dissemination in Europe of liberal and humanist ideas "that proclaimed the universal rights of man" and "the fight against slavery and trade both Western and Oriental" powers (Gonzalez, 1993, p. 157). Consequently, also African people had the right to eternal salvation, to freedom and to be agents of their own transformation. In his Plan, Daniel Comboni foresees the training of African people who would become teachers, "farmers, doctors, phlebotomists, nurses, pharmacists, carpenters, tailors, tanners, blacksmiths, builders, shoemakers" (Comboni, 2006, p. 862) and traders.

Daniel Comboni also specified about the need of creating universities and vocational training institutions in the centres previously mentioned (Comboni, 2006, p. 865). In order to implement this Plan, Daniel Comboni, not a member of the Mazza Institute anymore, founded in Verona the Institute for the Missions of Africa on June 1, 1867. This Institute would become a male Religious Congregation that is known today as the Comboni Missionaries of the Heart of Jesus. This Religious Institute is behind the foundation of dozens of schools in the Sudan in the XX century. 
"On the basis and as a result of my [the] Plan" (Comboni, 2006, p. 425), Daniel Comboni founded an Institute of Formation for African men and a second Institute for African girls in Cairo. The first one was entrusted to seven priests trained in the Institute for the Missions of Verona and the second one to four Sisters of Saint Joseph of the Apparition along with fourteen South Sudanese women teachers who had "been in Europe for ten years" (Comboni, 2006, p. 425). The goals of these Institutes in Cairo were two. The first one was "the religious, moral, intellectual and technical education of Africans [...] so that [...] they may return to the tribes of Africa to be apostles of faith and civilisation among the African peoples" (Comboni, 2006, p. 721). And the second one was "the acclimatisation of European missionaries [...]" and their training in the study of "Arabic, the African languages [...], the oriental customs and the ways of the Muslims [... and] a little medicine" (Comboni, 2006, p. 701).

From these goals and his writings it is possible to draw some principles that shape the educational vision that Comboni implemented in Sudan:

- It is a practice oriented education where the students experience and practice already during their learning process what they are studying. In fact, Comboni defines his Institutes of Cairo as "schools of experience" (Comboni, 2006, p. 815).

- It's instrumental to the purpose of "plant[ing] the faith solidly in Central Africa" (Comboni, 2006, p. 698).

- It is holistic as it deals with the spiritual, the intellectual, the social and the moral dimensions of the person.

- It is contextualized for the needs of Central Africa.

- It respects the inner freedom of the students to choose the way of life (catechist, Priest or Sister, craftsman...) in the light of the personal gifts and after a personal "counsel with God and their spiritual father" (Comboni, 2006, p. 718).

On January 1, 1872, Comboni also founded in Verona a Congregation of Sisters firstly called as Institute of the Pie Madri della Nigrizia and today known as Comboni Missionary Sisters. This religious congregation is behind the foundation of dozens of schools for girls in Sudan. 


\section{Naranjo-Escuelas católicas de la República de Sudán}

\section{The Educational Work of Daniel Comboni in the Sudan}

In 1871 eighteen Sudanese girls trained in Cairo returned to Sudan. With them, Comboni opened a school in El Obeid and resumed the activity of the school of Khartoum where they became "the most able teachers to catechize and educate the local people" (Comboni, 2006, p. 1028).

The school of El Obeid claimed the attention of the local inhabitants of the neighbouring Nuba Mountains. Kakum, the tribal leader (sultān) of Dilling, "decided to come in person to visit" Comboni and ask the opening of a missionary station in his town (Comboni, 2006, p. 1241-1242). Other chiefs "had asked [...] Kakum to make [Comboni...] decide to go and settle among them" (Comboni, 2006, p. 1067).

Comboni, already appointed Pro-vicar of Central Africa, responded positively to their request and also "opened the Mission in Berber in November 1874 [...] with premises for schools" (Comboni, 2006, p. 1187). As for Khartoum, the growing number of students "demanded the enlargement of the school buildings. On June 9, 1874, the sisters moved to the new brick building [...] built on the same style as the older part of the block" that had been finalized in 1856 (Toniolo \& Hill, 1974, p. 21).

In 1878 the school had 200 girls and 300 boys in addition to 80 African female boarders and 100 male ones. "The most skillful ones helped the Fathers in their teaching" (Santoni, 1905, p. 371). Most of them found work after leaving that school. "The 200 employees at the Khartoum dockyard were mostly former pupils of the mission school" (Hill, 1959, p. 127).

Daniel Comboni died in Khartoum on October 10, 1881 when he was fifty year old. His life, his generosity, his work and the main idea of his Plan, to regenerate Africa through African people, left a deep impact in Sudan.

\section{Comboni Schools during the Condominium (1898-1956)}

\section{Introduction to the Period}

In 1881 a Sudanese religious leader called Moḥammed Aḥmad bin 'Abd Allah proclaimed himself the Mahdī, with the mission of "purifying Islam and make it return to its primitive integrity" (Ballin, 2001, p. 187). His 


\section{HSE - Social and Education History, 7(2) 91}

proclamation got impetus from the widespread resentment among the Sudanese population towards the oppressive policies of the Turco-Egyptian rulers and from their religious expectations (Ballin, 2001, pp. 209-215).

Al-Mahdī conducted a successful military campaign that led his soldiers until the conquest of country. The Christian community was obliged to convert into Islam and the missionaries were taken as prisoners first to El Obeid in 1883 and then to Omdurman in 1885. The work of Comboni in Sudan looked to be destroyed.

But outside the country, a decision would have an important impact on the field of education in Sudan. The Institute of the African Missions founded by Daniel Comboni in Verona in 1867 became a Religious Congregation on October 28, 1885 under the name of Sons of the Sacred Heart of Jesus. This Congregation would give continuity to the work of Comboni and was known in some English speaking countries as Verona Fathers. Their name was changed into Comboni Missionaries of the Heart of Jesus in 1979.

In January 1899, after defeating the Mahdist State, the AngloEgyptian army restored Egyptian rule in Sudan but as part of a condominium, or joint authority, exercised by the British Empire and Egypt. The colonial government implemented two differentiated policies in the North and the South of Sudan. The so called Southern Policy, in force until 1946, aimed at eliminating any kind of Arab-Islamic influence and at developing local cultures in the South (Sundkler, 2001, p. 691-693; Vantini, 2005, p. 532). At the same time, the Government did not invest in education in the South until 1926 as its policy "was to tolerate rather than to encourage education" (Sanderson, 1962, p. 105). Thus they left the provision of education to missionary societies like the Anglican Church Missionary Society, the Comboni Missionaries, the Australian and New Zealand Sudan United Mission and the American United Presbyterian Mission without even contributing economically in that first period. The Government would gradually "took an increasing interest in educational matters which gradually led to direct intervention by means of financial subsidies and later by provision of government schools as alternatives to mission education" (Sanderson, 1962, p. 108-109).

In the North the Mahdist regime had closed missionary and state schools and left a network of 1,500 khalāwi that provided literacy and Koranic 


\section{Naranjo-Escuelas católicas de la República de Sudán}

learning to 60,000 children (Mohammed K. Osman, 1979, p. 356). The new colonial government created a network of elementary schools (kuttāb) "that was supposed to replace the existing khalāwi in the longer run" (SeriHersch, 2017, p. 4) and coexisted with Egyptian schools, missionary schools, community schools and Sudanese private schools.

The first director of education of the colonial period, James Currie (19011914) defined the priorities for his department as the creation of a "native artisan class"; spreading education among the "masses of the people" in a way that would enable them to "understand the merest elements of the machinery of government; and the creation of a "small native administrative class who will ultimately fill many minor government posts" (Gordon Memorial College Annual Report and Accounts, 1901, p. 9; cited by Beshir, 1969, p. 29).

\section{The Spreading of Missionary Schools: Need and Caution}

The new colonial government authorized in October 1899 the return of the missionaries of Comboni. The Apostolic Vicar, Mons. Roveggio, arrived in January 1900, and immediately opened in Omdurman a school for boys and another one for girls (St. Joseph Girls' Schools), that consisted of Kindergarten, Primary One and Two.

In 1902 the missionaries opened another small school for boys in the plot where the Catholic Cathedral of Khartoum is located today (Vantini, 2005, p. 120). This plot was given to the Catholic Church in compensation for the one taken by the Colonial government where the old site of the Apostolic Vicar was. In 1903 the Comboni Missionary Sisters also opened a school for girls called Saint Anne in the centre of Khartoum. Those two schools and a Government school, the Gordon Memorial College, were the first schools of the city of Khartoum. In 1912 the number of students at Saint Anne reached 162 and 227 in 1923 (Sa'ād, 2002, p. 58). The successor of Mons. Roveggio, Mons. Franz Xavier Geyer, opened a coeducational school in Port Sudan and another for girls in Halfaya (Khartoum North) before 1905. During his twenty years as Apostolic Vicar of Khartoum (1903-1922), Mons. Geyer, "made of the Catholic school the first priority of his plan for the North by developing the existing ones and extending and raising their level" (Vantini, 2005, p. 126). 
In a context of great scarcity of educational opportunities, many Sudanese Muslim families applied to have their boys and girls enrolled in the schools of the missionaries. These Muslim students needed a written permission from their parents and were exempted from the lessons of Christian religion but the educational vision had a Christian foundation and outlook. Nonetheless, these schools "came to be accepted by both the administration and the local population as useful contributors to education and pioneers of girls' education" (Sundkler, 2001, p. 147). "The first girls' schools in the twentieth-century Sudan were established by the Italian Roman Catholic Verona Fathers" (Sanderson, 1961, p. 95)

In 1905 the Government created a body to supervise that Muslim students in mission schools were not encouraged to conversion. This supervising section became a way of controlling education and avoiding any conspiracy against the established power (Sa'ād, 2002, p. 54). The colonial government was still reluctant to a full opening of education opportunities for the local people and to the presence of the missionaries. In fact, the British Consul General, Lord Cromer, did not really want the missionaries in Sudan (Cromer, 1900; cited by Sanderson, 1961, p. 127).

In 1925 the Governor of Sudan invited the new Apostolic Vicar of Khartoum, Mons. Paolo Tranquillo Silvestri, to reopen the mission of Dilling. But "he refused the invitation in order to concentrate his personnel in South Sudan" (Vantini, 2005, p. 135). On the same year, this Bishop closed the Catholic Mission Boys' School in Khartoum and Comboni Boys' School in Omdurman. The Vicariate suffered from "financial problems" (Sa'âd, 2002, p. 58; Vantini, 2005, p. 364) and the Bishop preferred to concentrate the limited resources on the activities of evangelization in the South.

The school of Omdurman would be reopened in 1931 by the successor of Mons. Silvestri who also opened Comboni Sisters' School in 1928 in Khartoum. The Catholic Mission Boys' School of Khartoum instead will not reopen any more. As a reaction to the policy of Mons. Silvestri, the Comboni Missionaries decided in their General Chapter of 1925, to open a Secondary school in Khartoum under the name of Comboni College Khartoum (CCK). This school would educate from the forties great part of the Sudanese elite of the independent Sudan. It is worth mentioning that 


\section{Naranjo-Escuelas católicas de la República de Sudán}

"inaugurated in 1902 by Kitchener, the Gordon Memorial College was Sudan's single secondary school” (Seri-Hersch, 2017, p. 5).

Comboni College Khartoum was authorized by the colonial authorities "on the conditions that the school is for non-Sudanese [sic] boys" (Director of Education, May 26, 1929). This condition appears in a "strictly confidential" letter while it is not present on a non-confidential version signed one day after (Director of Education, May 27, 1929).

In 1933 CCK became official site for the Oxford Certificate, which allowed the students, non-Sudanese yet, to continue their education in British universities. In order to keep that accreditation, the Congregation of the Comboni Missionaries sent periodically some priests to study in British universities, which gave CCK a very high standard and fame in the whole of Africa.

The creation of Comboni College coincided with the call for educational expansion and reform that repeatedly appeared in the Arabic press of Khartoum from some Sudanese leaders since the 1930s. One of them, Muhammad Aḥmad Mahjūb, who would become Minister of Foreign Affairs of the Independent Sudan (1956-1958) and Prime Minister later on (1965-1966 and 1967-1969) wrote an article in Al-Fajr newspaper (1934, pp. 471-477) asking the colonial government to revise the educational aims and curricula of the Gordon Memorial College along the model of British secondary schools instead of reducing their aim to the training of a limited and controlled number of civil servants. A few months later, an editorial in the same magazine was unambiguously titled "Give Us Education ( 'allimūnā) and leave us alone" (1935, pp. 1065-1066).

On October 13, 1936 Sir Lancelot Oliphant, deputy under-secretary of State, accused the British authorities in Sudan of neglecting "the education of the natives and, instead, had concentrated solely on efficient government" (Foreign Office 407/219; quoted by Warburg, 2003, p. 97).

In 1938, 'Abd-el-Raḥmān al-Mahdī, son of Moḥammed Aḥmad alMahdī, presided over the awards' ceremony to the best students of Comboni College Khartoum. Impressed by the quality of the institution, he registered some members of the family in the school in 1940 (Vantini, 2005, p. 515).

On April 19, 1944, the Colonial Government canceled the restrictions for Muslim Sudanese students to register in church schools (Vantini, 2005, p. 517). According to Sa'ād 'Abd Al-'Azīz, the doors were fully open for them 
after the Second World War (2002, p. 59). Nonetheless, the Annual Report of the Education Department already reported 36 Sudanese students at CCK in 1937 (1937, Appendix V). The number of Sudanese students at CCK grew up very quickly after the end of the restrictions. The three children of the Minister of Education, 'Abd-el-Rahmān al-Mahdī, and some members of the Mirgani family, two of the most prominent families in Sudan, studied at CCK. One of those students, Sādiq al-Mạ̣dī would become Prime Minister of Sudan in 1966 and 1986.

In 1949 CCK was "recognized as exams centre of the London Institute of Bookkeepers" (Vantini, 2005, p. 519). It became the point of reference for those who wished to study sciences and commerce while the Gordon Memorial College continued training civil servants for the Government. An expression of the high level of CCK was the fact that in 1950, 92,5\% of its students succeeded in the University of Oxford School Certificate.

The bishop of the time was Mons. Francesco Saverio Bini. He believed that "Catholic Schools was the best way of service in the North" (Vantini, 2005, p. 492). His successor, Mons. Agostino Baroni, who had been the principal of Comboni College Khartoum, opened the missions and the schools of Dilling, Kadugli, An-Nahud and El- Fasher in (Vantini, 2005, p. 510) and a Vocational Center in 1952 (St. Joseph Technical School). The Comboni Missionary Sisters opened another school in Khartoum, Villa Gilda School, in 1953. A characteristic of the Catholic Schools of the period was their religious diversity as they included "Christian, Hindu, Jew, pagan and Muslim students" (Sa'ād, 2002, p. 62).

All these schools were administratively independent from the Ministry until 1948 when "a unified educational policy began to be adopted for the northern and southern Sudan" (Sanderson, 1963, p. 69). The only aspect where they always had a close eye from the Government was on the issue of religious instruction because of the fear to provoke reactions from the fanatics.

Catholic Schools developed in an extraordinary way because "there was more demand for boys' education in the northern Sudan than the government could provide" (Sanderson, 1963, p. 74). The same statement could be applied to girls' education. Just some years before the independence (1956), the colonial government invested seriously in education. By that time, "elementary schools catered for 76,996 pupils, while intermediate schools 


\section{Naranjo-Escuelas católicas de la República de Sudán}

counted only 4,675 pupils and secondary schools 1,700 pupils; some 722 students were then enrolled in higher education" (Beshir, 1969, p. 208).

\section{Comboni Schools during the Independent Sudan}

The independence of Sudan on January 1, 1956 opened a new era for Comboni Schools. This period (1956-2017) is signed by some historical events that had a great impact on them and on the country: the two Civil Wars between the South and the North (1955-1972 and 1983-2005), the Arabization-Islamization of the educational curricula in 1992 and the independence of South Sudan in 2011.

\section{Independence, Sudanization, Arabization and Islamization}

In July 1956 the Minister of Education of the independent Sudan, 'Uthmān Ziada Arbāb, announced that the Government would "take over" (Vantini, 2005, p. 544) the schools of the missionaries in the South. In 1960 these schools passed to be under the jurisdiction of the Ministry of Education that established for them the official curricula that was in force in the North.

In Khartoum instead, CCK and other Comboni schools continued their development without great problems and with a growing number of Sudanese students who, in 1959, reached a percentage of $73.6 \%$ at CCK. These schools (CCK, Bahri, Saint Francis and Villa Gilda) had 379 High School male students (all at CCK) and 171 girls, 629 boys (365 at CCK) and 404 girls in intermediate and 450 boys (just 86 at the just started Primary Section of CCK) and 552 girls in Primary (Figli del Sacro Cuore, 1961, p. 319).

In 1964 the Government issued the Missionary Act that commanded the expulsion of the missionaries working in the South of the country. They were accused of supporting the revolt of the rebels that had started in 1955 and resulted into the First Civil War between the North, self-defined as Arab and Muslim, and the South, more identified with African cultures.

Some members of the Government pressurized to have the missionaries expelled also from the North of the country. But others were former students of Comboni College Khartoum and kept a very positive esteem of the work of the missionaries in that institution. Nonetheless a good number of foreign teaching staff of Comboni College left the country after the riots that took 
place in Khartoum on December 6, 1964 between South Sudanese people and Northerners that would eventually ended up with the killing of 250 people. The triggering incident was the rumor of the death of the highestranked Southern member of Prime Minister al-Sirr's cabinet, Interior Minister Clement Mboro (Rolandsen \& Daly, 2016, p. 83).

After those events, the ongoing process of sudanization of the teaching staff of CCK and other Comboni Schools accelerated:

Table 1

Sudanization of CCK teaching staff (Vantini, 2005, p. 519; Figli del Sacro Cuore di Gesu, 1947, 1955; Comboni Missionaries, 1994, 2000; Comboni College Khartoum, 1959)

\begin{tabular}{cccc}
\hline Year & $\begin{array}{c}\text { Percentage of CCK } \\
\text { Sudanese teaching } \\
\text { staff }\end{array}$ & \multicolumn{2}{c}{ Number of Comboni Missionaries working at } \\
CCK
\end{tabular}

The diminution of the presence of the Comboni Missionaries among the teaching staff of the College had also to do with the transfer of personnel to the zones where the displaced people coming from the South because of the Civil War were settling in order to minister to them. 
Moreover, in 1993 the Ministry of Education of Khartoum State issued a decree according to which the headmaster and the vice-headmaster of every private school should be Sudanese (Vantini, 2005, p. 520) and couldn't be a foreigner. This decision was taken in the context of the reform of the educational system that took place in 1992.

After the independence of the country in 1956, the educational system of the colonial period had continued in force until 1992 when the Government of 'Omar Al-Bashīr issued the General Education Organization Act that defined "objectives, examination regulations, educational policies and general administration" (UNESCO, 2012, p. 2). The perception in the new government was that the educational system had been adapted from a foreign model without relation to the cultural roots of Sudan so that "most students who completed the Secondary School bore Sudanese features and British minds" (Fawzia, 2006, p. 25). In order to correct this situation and "shape the Sudanese person integrated spiritual, moral, intellectual and physically" (Fawzia, 2006, p. 18), the government started a policy of Arabization and Islamization of all the educational levels, as they were identified as the two main characteristics of Sudanese identity.

The new educational system brought also a new distribution of the educational stages. The following chart presents it along with the previous ones: 
Table 2

Educational systems in Sudan. Source: Own elaboration.

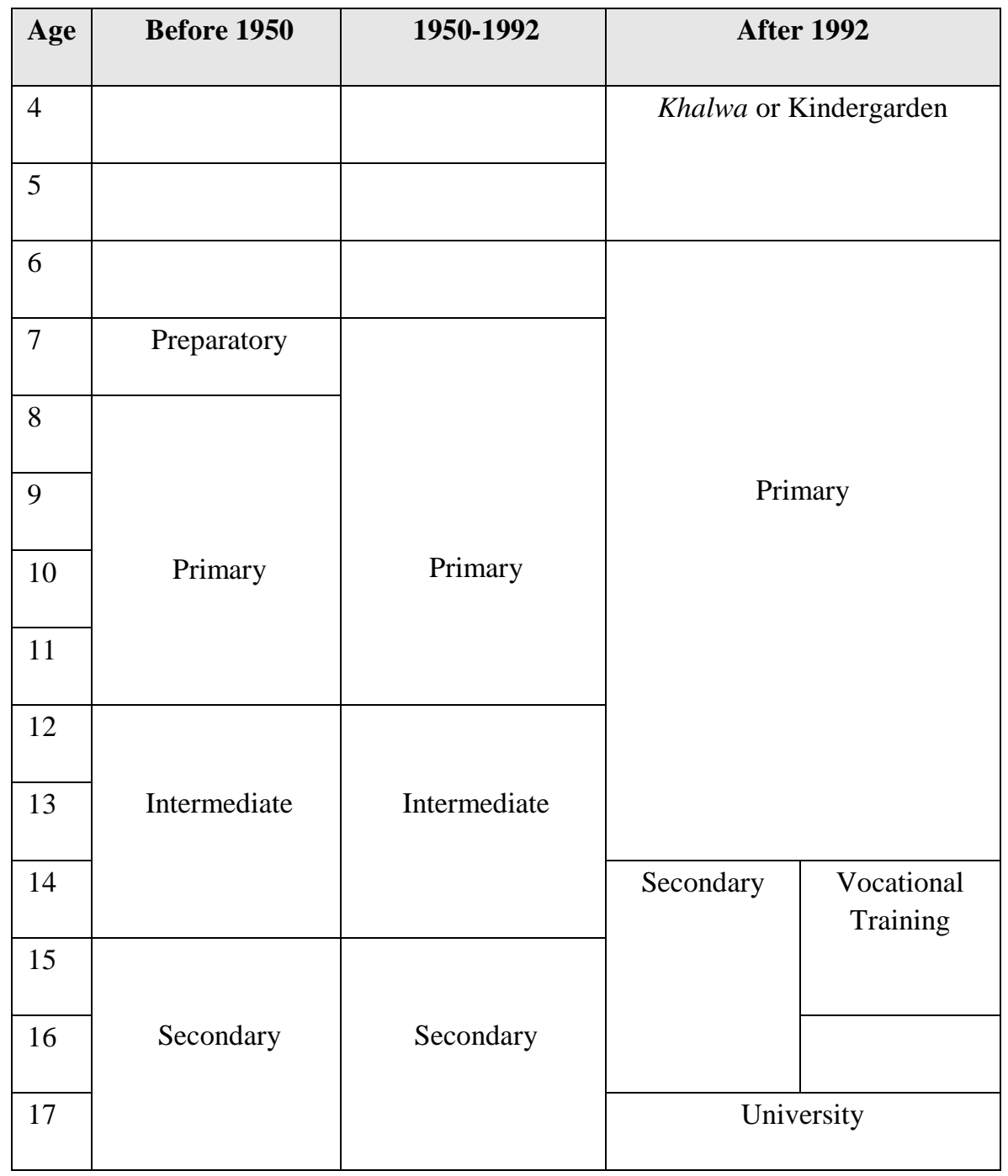




\section{Naranjo-Escuelas católicas de la República de Sudán}

This policy was also applied to the Southern region of the country, inhabited by different Black-African ethnic groups. Sudan at the time had 2.5 millions of square meters and about 500 ethnical groups. With the new educational system, the responsibilities of general education were distributed between the Federal Ministry of Education -that remained responsible for planning, curriculum development and teacher training-, the State Ministries and the Municipalities (Arora, 2003). This decentralization implied a huge diminution in the allocations for education that diminished from $15 \%$ of the total budget for the 1985-1986 academic year to $1.7 \%$ for the $1992-1993$ one (Wani, 2002, p. 13).

A new stage in the history of Sudan started with the signing of the Comprehensive Peace Agreement (CPA) in January 2005 between the two warring parties, the central Government of Khartoum and the Sudan People Liberation Movement (SPLM). This agreement included the elaboration of "a national curriculum framework that addresses the multicultural, multiethnic, and multi-religious context of Sudan" (World Bank, 2012, p. 26). This new curriculum was never implemented and the Independence of the Republic of South Sudan in 2011 opened the way to a new emphasis in the Islamic and Arab character of the Sudan.

\section{The Impact of the Civil Wars and the Development of Emergency Schools}

The second element that signed this period of history (1956-2017) and the role of the schools of the Catholic Church in Sudan were the two Civil Wars between the North and the South of the country. In 1955 a group of Southern Sudanese soldiers had started a mutiny against the Central Government of Khartoum. This rebellion became a Civil War that pushed thousands of Southern Sudanese displaced people towards the "Arab" North.

A Peace Agreement was signed in 1972 that closed the first period of war. But in 1983 the attempt to impose the Islamic Law in the South arose a new military reaction in the South. This second stage of the conflict was much more violent and generated the displacement of more than 4 million people. In fact, "displacement became a deliberate strategy of the armed groups" (Geoffroy, 2007, p. 6). About 1,8 million displaced people settled around Khartoum by 2004 (Global IDP, 2005, p. 66). In addition to this, the advance of the desert in the West and the North of the country and the severe 
droughts were also factors behind the massive displacement of people from the peripheries towards the capital. The population grew in that area grew from $1,801,850$ in 1983 to $3,612,538$ in 1990 (Davies, 1991; quoted by Geoffroy, 2007, p. 6).

In 1986 the Archdiocese of Khartoum of the Catholic Church started an emergency educational program for the Internal Displaced Persons (IDPs). It opened 48 educational centres that catered "for 8,500 students mainly in Khartoum" with the aim of enabling the displaced children "to enter the government primary school, and this was to be done up to the third grade of education" (Wani, 2002, p. 5). It's necessary to consider that the "majority of the children were considered over-aged to be accepted in the government regular schools" (Wani, 2002, p. 11) that, in addition to it, had also lack of space and resources.

According to UNICEF (1996), there was one school available for 512 children in the school-going age of 6-13 years, one for every 431 children in the North and one for every 3,417 children in the South. Moreover, these displaced children from the South did not know enough Arabic "to enable them to study in the government schools" (Wani, 2002, p. 9). Certainly, it was also very difficult for municipalities to deal with such a great challenge as the presence of refugees was. With the new General Education Organization Act, local councils were supposed to pay for textbooks, teachers' salaries... The integration of displaced children was beyond their capacities. In fact, some municipalities asked the Catholic Church to extend their educational offer beyond the fourth grade of basic school instead of having the students sent to government schools, as initially planned by the emergency program (Wani, 2002).

This program was called "Save the Savable" and developed thanks to the support of external donors. In 2002 the number of educational centres reached 90 and the number of students 54,000 from pre-school level to primary eight. Therefore, at the end the program instead of facilitating the insertion of these children in government schools became "a parallel program to the regular government education program" (Wani, 2002, p. 5) that educated not just Christian children. Displaced people from other regions, mainly Darfur and Nuba Mountains, also settled in the peripheries of the capital and benefitted from these schools. 


\section{Naranjo-Escuelas católicas de la República de Sudán}

At the beginning, the so called "Save the Savable Schools" were distinguished from the previously existing "Comboni Schools", but after the beatification of Saint Daniel Comboni in 1996, even the first ones came to be known as "Comboni Schools" (Wani, 2002, p.11). One of the differences between these two kinds of schools was that the latter ones were normally self-sufficient, at least for the ordinary running, while the first ones depended from foreign funding.

Sa'ād 'Abd Al-'Azīz affirms, quoting Fahmī Suleimān, Director of the Biblical Society in 1977, that Catholic schools were financed by the Vatican (2002, p. 58). This is a quite generalized conviction in Sudan. Nevertheless, most external donors of the "Save the Savable Program" had nothing to do with the Vatican. These donors were Misereor, NGO of the Catholic Church in Germany, Cafod a NGO of the Catholic Church in England and Wales and Bilance and Christian Blind Mission (CBM), two Dutch NGOs.

The Comboni Schools outside the "Save the Savable Program" in Northern Sudan, in January 1994, were seventeen and had 13,055 students. 6,784 pupils were Christians, 6,209 were Muslims and 62 were neither Christians nor Muslims (Education Office, 1994).

In 2002 the Archdiocese of Khartoum was running 13 Comboni Schools, "about 212 pre-school (Kindergartens) and basic schools [...] serving a total of about 71,000 pupils, the majority of them are Christians, with a total of 1,832 teachers and 770 auxiliary staff" (Wani, 2002, p. 11)

Given the poor living conditions of these displaced families, with the pass of time, this program was enriched with a school feeding program "operating in about 95 centres in Khartoum covering about 47,000 pupils in addition to over 1,200 teachers and 540 support staff' (Wani, 2002, p. 5).

The impact of Save the Savable Program in the extension of the educational service of the Catholic Church can be seen in this chart that contains the number of students coming for these schools who sat for the General Primary Education Certificate (GPEC): 


\section{HSE - Social and Education History, 7(2) 103}

Table 3

Development of Comboni Schools under Save the Savable Program: 1987-2002.

(Wani, 2002, p. 35)

\begin{tabular}{|c|c|c|c|c|c|c|c|}
\hline Year & Centers & Classes & Teachers & Pupils & Staff & $\begin{array}{c}\text { Pupils } \\
\text { who sat } \\
\text { for } \\
\text { GPEC }\end{array}$ & $\begin{array}{l}\% \text { of } \\
\text { pass }\end{array}$ \\
\hline $\begin{array}{l}1987- \\
1988\end{array}$ & 48 & 250 & 250 & 8,500 & 150 & - & - \\
\hline $\begin{array}{l}1988- \\
1989\end{array}$ & 52 & 295 & 302 & 10,300 & 175 & - & - \\
\hline $\begin{array}{l}1989- \\
1990\end{array}$ & 60 & 390 & 345 & 17,200 & 200 & - & - \\
\hline $\begin{array}{l}1990- \\
1991\end{array}$ & 68 & 430 & 510 & 22,100 & 220 & - & - \\
\hline $\begin{array}{l}1991- \\
1992\end{array}$ & 70 & 450 & 590 & 23,500 & 270 & 320 & 83 \\
\hline $\begin{array}{l}1992- \\
1993\end{array}$ & 71 & 470 & 620 & 27,600 & 280 & 400 & 85 \\
\hline $\begin{array}{l}1993- \\
1994\end{array}$ & 72 & 480 & 720 & 31,500 & 302 & 420 & 72 \\
\hline $\begin{array}{l}1994- \\
1995\end{array}$ & 75 & 499 & 900 & 35,300 & 320 & 450 & 68 \\
\hline $\begin{array}{l}1995- \\
1996\end{array}$ & 79 & 596 & 1110 & 39,500 & 320 & 507 & 60 \\
\hline
\end{tabular}


104 Naranjo-Escuelas católicas de la República de Sudán

Table 4

Development of Comboni Schools under Save the Savable Program: 1987-2002.

(Wani, 2002, p. 35) (continued)

1996-

$82 \quad 798$

1150

41,600

325

1389

72

1997

$1997-$

87

810

1200

$44,500 \quad 350$

1737

72

1998

1998-

85

699

985

$42,112 \quad 484$

1725

71

1999

1999-

89

798

1025

45,154

514

1834

81

2000

2000-

90

790

1078

48,172

549

2777

79

2001

2001-

87

784

1179

46,267

519

2002 
The growth in the number of students can be visualized in this chart:

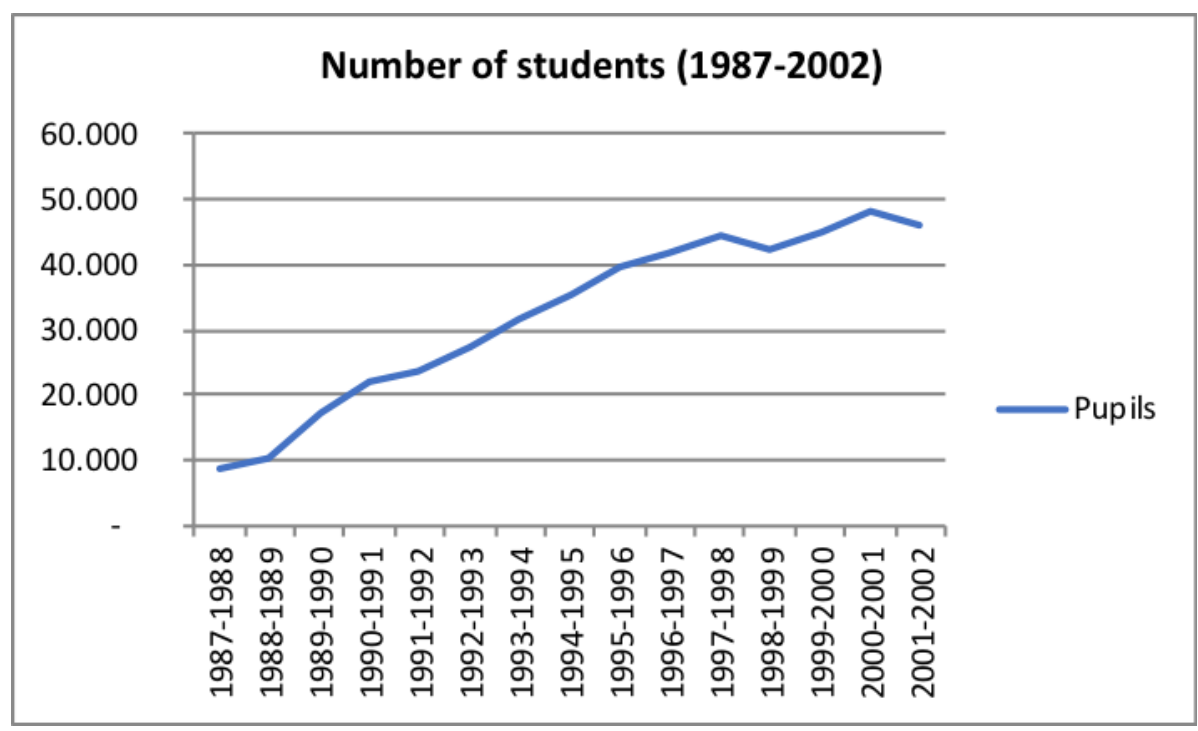

Graphic 1. Growth in the number of students of the Save the Savable Program (1987-2002). Source: Own elaboration based upon data of Table 4.

"Save the Savable" improved access to education for the children of the IDPs families. It also gave the possibility to Christian parents to have their children studying in a kind of school coherent with their religious beliefs.

The Program was run by an Office that was part of the Education Office of the Archdiocese of Khartoum of the Catholic Church with certain independence from it. In their evaluation, the team in charge of the Program stated that the number of schools was too big to serve the objective of quality and therefore suggested "eliminating those schools that have very few children and those others that are located close to each other" (Wani, 2002, p. 9).

Another critical issue of the report is the "Church Dependency Syndrome" (Wani, 2002, p. 7). Supported by foreign organizations and considering the poverty of the population, these schools were free of charge. 


\section{Naranjo-Escuelas católicas de la República de Sudán}

This fact conditioned the sustainability of the project and became a problem that led to the closure of the program in 2010, after the progressive withdrawal of the donors that logically considered that an emergency program should have a limited time duration.

Every Parish was supposed to reduce the number of schools that were under its territory and choose two as maximum. These selected schools became "Community Parish Schools" under the responsibility of the Parish Priest. Normally, the Parishes identified the schools with better premises and a community that had showed readiness to pay the school fees and guarantee, in this way, its self-reliance. Some schools, discarded by the Parishes, were assumed by Associations of Teachers and are not considered "Comboni Schools" anymore.

According to the data of the Education Office of the Archdiocese of Khartoum (2017), the 52 schools of the Catholic Archdiocese of Khartoum host 25,882 students. $12,583(48,73 \%)$ are boys and $13,239(51,27 \%)$ are girls; $10,875(41,52 \%)$ are Muslims and 15,317 are Christians $(58,48 \%)$; $15,356(63,50 \%)$ are Sudanese and 8,825 (36,50\%) are foreigners, mainly South Sudanese.

The rest of the territory of the modern Sudan at ecclesiastical level is part of the Diocese of El Obeid. This one is divided into fourteen parishes. Most of them have schools but there are no statistics about.

\section{Conclusions}

The Catholic Church opened schools in Sudan in the XIX century as alternative to the Quranic schools (khalāw $\bar{l})$ for the small Christian minority, as instrument for the education of local catechists and for the so called "civilization" of the continent. But from the beginning of the twentieth century, the Sudanese Muslim population searched for those schools as they represented a qualified way of achieving an integral and complete education for their children when the offer was so scarce. This mixing of Christian and Muslim students became a laboratory of interreligious tolerance and mutual understanding and esteem that has shaped Sudanese society. This dialogic relation enlarged the target and mission of these schools beyond their initial limited ones. 
While in the first decades of the XX century, those schools were mainly associated with the concept of quality education, from the eighties onward, the stress fell on the dimension of equity as their number multiplied to provide instruction to refugees, displaced and marginalized people of the outskirts of the main cities of Sudan.

This journey through history has also shown that these schools had also a conflictual relation with groups of power or trends inside the different governments. At the beginning of the Condominium, the British authorities were afraid of provoking a reaction from mahdist supporters or fundamentalist groups that could interpret a collaboration with the missionaries as part of a strategy for the evangelization of the country. Moreover, during the first decades of their ruling, the colonial power thought of an instruction designed for their mere administrative needs and was reluctant to provide a solid education to the local population.

Later on, some Islamist trends inside the government of the independent Sudan considered Catholic schools as foreign instruments of evangelization and obstacles for the islamization of the country.

In spite of all this, Catholic schools developed through history and laid down roots in Sudan because they respected the inner freedom of their students, were appreciated by the local population and were flexible enough to adapt themselves to the changing needs and demands of the Sudanese society.

\section{Notes}

${ }^{1}$ Propaganda Fide was the department of the Roman Curia (the central administration of the Catholic Church) led by a cardinal in charge of the missionary activity of the Church. It is currently named Congregation for the Evangelization of Peoples.

${ }^{2}$ A Pro-Vicar is someone who acts as a Vicar in the absence of this one.

\section{References}


108 Naranjo-Escuelas católicas de la República de Sudán

al-Mu tasim A. al-Hāajj (2005). Al-khalāwī fĩ al-Sūdān: nuzumuhā warusūmuhā ḥattā nihāyat al-qarn al-tāsi' 'ashar. Omdurman: Markaz Muḥammad 'Umar Bashīr li-l-dirāsāt al-sūdāniyya.

Arora, G.L. (2003). Sudan basic education sub-sector study. Analysis of curriculum and suggestions for a National Curriculum Framework. Paris: UNESCO.

Ballin, C. (2001). Il Cristo e il Mahdi: la comunità cristiana in Sudan nel suo contesto islamico con particolare riguardo al periodo della rivoluzione mahdista, 1881-1898. Bologna: EMI.

Bano, L. (1979). Lazzaristi a Khartoum (1842-1845). Roma: Pontificia Universitas Urbaniana.

Beshir, M.O. (1969). Educational development in the Sudan, 1898-1956. Oxford: Oxford Clarendon Press.

Comboni, D. (2006). Writings. London: Comboni Missioanries.

Comboni College Khartoum (1959). Thirtieth Anniversary Issue. Verona: Nigrizia.

Davies, H.R.J. (1991). Population change in the capital region. In M.E. Abu Sin \& H.R.J. Davies (Ed.). The future of Sudan's capital region: a study in development and change (pp. 132-141). Khartoum:

Khartoum Press University.

Fawzia Țaha Mahdī (2006). Taqwim marhala al-ta 'līm al-asāsī fì wilāyat Al- Khartūm. Al- Khartūm: Jāmi'a Al-Khartūm lil-nashr.

Figli del Sacro Cuore (1947). Catalogo della Congregazione dei Figli del Sacro Cuore di Gesù al 1 gennaio 1947. Verona: Istituto Missione Africane.

Figli del Sacro Cuore (1955). Supplemento al Catalogo di 1954 della della Congragazione dei Figli del Sacro Cuore di Gesu. Primavera 1955. Verona: Istituto Missione Africane.

Figli del Sacro Cuore (1/1/1961). Bollettino della Congragazione dei Figli del Sacro Cuore di Gesu. N. 56. Verona: Istituto Missione Africane. Geoffroy, A.De (October 23-25, 2007). From Internal to International Displacement in Sudan. In Migration and Refugee Movements in the Middle East and North Africa. The Forced Migration \& Refugee Studies Program of the American University in Cairo. Cairo. Global IDP (2005). Profile of Internal Displacement: Sudan. Compilation of the Information Available in the Global IDP Database of the 
Norwegian Refugee Council. Geneva: Norwegian Refugee Council/Global IDP Project.

Gonzalez, F. (1993). Comboni en el corazón de la misión africana. El movimiento misionero y la obra comboniana: 1846-1910. Madrid: Mundo Negro.

Hill, R. (1959). Egypt in the Sudan, 1820-1881. New York: Oxford University Press.

Lozano, Juan Manuel (1996). Vostro per sempre. Bologna: EMI.

Missionari Comboniani (1994). Annuario Comboniano (1994). Roma:

Missionari Comboniani.

Missionari Comboniani (2000). Annuario Comboniano (2000). Roma: Missionari Comboniani.

Mohammed K. Osman (1979). The Rise and Decline of the People's (Ahlia) Education in the Northern Sudan (1927-1957). Paedagogica Historica, 19(2), 355-371. Retrieved from https://eric.ed.gov/?id=EJ258617

Mohạamed Ibrahīm Abū Salīm (1991). Tārīkh al- Kharțūm. Beirūt: Dar Al-J̄̄l Muḥammad Aḥmad Mạ̣jūb (November 1, 1934). Fī al-ta 'līm. Al-Fajr newspaper, pp. 471-477.

Muḥammad Aḥmad Maḥjūb (June 16, 1935). Allimūnā. Al-Fajr newspaper, pp. 1065-1066.

Ritter, C. (1852). D. Ignaz Knoblehers Reise auf dem weissen Flusse. Monatsberichte d. Berliner Ges. Für d. Orient, IX.

Rolandsen, Ø. H. \& Daly, M.W. (2016). A History of South Sudan. From Slavery to Independence. Cambridge: Cambridge University Press. Sa'ād 'Abd Al-'Az̄̄z Aḥmad (2002). Al-ta'līm al-ajnabì fì-al-Sūdān 18981956. Al-Khartūm: Dār Jāmi’a Al-Khartūm lil-nashr.

Sanderson L.M. (1961). Some aspects of the development of girls' education in the Northern Sudan. Sudan Notes and Records, 42, 91-101.

Sanderson, L.M. (1962). Educational Development in the Southern Sudan, 1900-1948. Sudan Notes and Records, 43, 105-117.

Sanderson L.M. (1963). A survey of material available for the study of educational development in the modern Sudan, 1900-1963. Sudan Notes and Records, 154, 69-81.

Santoni, L. (1905). Alto Egitto e Nubia: Memorie di Licurgo Santoni (18631898). Roma: Librai Editori. 
110 Naranjo-Escuelas católicas de la República de Sudán

Seri-Hersch, I. (2017, Feb). Education in Colonial Sudan, 1900-1957. In Spear Thomas (ed.), Oxford Research Encyclopaedia of African History. Oxford. doi: 10.1093/acrefore/9780190277734.013.12

Sundkler B. \& Steed, C. (2001). A History of the Church in Africa.

Cambridge: Cambridge Univ. Press.

Toniolo, E. \& Hill, R. (Eds) (1974). The Opening of the Nile Basin. Writings by Members of the Catholic Mission to Central Africa on the Geography and Ethnography of the Sudan 1842-81. London: C. Hurst.

UNESCO (2012). World Data on Education. VII Ed. 2010/2011. Retrieved from http://www.ibe.unesco.org/sites/default/files/Sudan.pdf

UNICEF (1996). The situation analysis of Children and Women in the Sudan. Oxford: Oxford University Press for UNICEF.

UNICEF Sudan (2017). Consolidated Strategy Note for the Country

Programme of Cooperation 2018-2021 in Sudan. Khartoum.

'Uthmān bn Ḥamad Allah bn al-Ḥāj (1949). Sahm Al- 'Arūba. Al-juz' alawwal nizāman wa sha'ran haula al-tarīkh wa qabā'il al- 'Arab bial-Sūdān. Al-Khartūm: Maktaba al-nahḍa al-sūdānyia bil- Khartūm.

Vantini, G. (2005). La missione del cuore. I comboniani in Sudan nel ventesimo secolo. Bologna: EMI.

Vanzan, Piersandro (1996). Daniel Comboni: stratega della nuova missionerietà in Africa. La Civiltà Cattolica, Anno 147, Vol. II, quaderno $3500,110-122$.

Warburg, G. (2003). Islam, Sectarianism and Politics in Sudan Since the Mahdiyya. London: Hurst and Company.

World Bank (2012). The status of the education sector in Sudan (Prepared by the World Bank and the Government of National Unity of the Republic of Sudan). Africa Human. Development Series. Washington DC.

Yahya M. Ibrāhīm (1987). Ta 'rīkh al-ta 'ìmm al-dīnī fì al-Sūdān. Beirut: Dār al-jī1.

Zomrawi, N. \& Eisa, E. (2017). Analysis of Basic Education Extension in Khartoum State using GIS. International Journal of Innovative Research in Science, Engineering and Technology, 6(5). Retrieved from http://www.rroij.com/open-access/analysis-of-basic-educationextension-in-khartoum-state-using-gis-.pdf 


\section{Archival Sources}

Director of Education (1929, May 26). [Letter to the Secretary of the Italian

Catholic Mission. D.E.S/ 29-5-“C"]. Provincial Archives of the

Comboni Missionaries. Box E01, Folder 1/3). Khartoum Bahri.

Director of Education (1929, May 27). [Letter to the Secretary of the Italian

Catholic Mission. D.E.S/ 29-5-“C"]. Provincial Archives of the

Comboni Missionaries. Box E01, Folder 1/3). Khartoum Bahri.

Education Department (1937). Annual Report of the Education Department.

Retrieved from the Provincial Archives of the Comboni

Missionaries (Box D30, Folder 6). Khartoum Bahri.

Education Office (1994). [Yearly statistics]. Archives of the Education

Office of the Archdiocese of Khartoum (non-catalogued). Khartoum.

Education Office (2017). [Yearly statistics]. Archives of the Education

Office of the Archdiocese of Khartoum (non-catalogued). Khartoum.

Wani Gore, P. (2002). Report on: A Comprehensive evaluation of the program of education in Archdiocese of Khartoum, including the school feeding program. Unpublished work. Archives of the Education Office of the Archdiocese of Khartoum (non-catalogued). Khartoum.

Jorge Carlos Naranjo Alcaide: Principal of Comboni College of Science and Technology. Sudan University of Science and Technology

ORCID ID: http://orcid.org/0000-0002-4287-5900

Contact Address: naranjoalcaide@ hotmail.com 